\title{
Traveling ideas: Equality and Power Play around "Diversity" at North-West University (NWU), South Africa
}

\author{
Frans Kamsteeg \\ VU University Amsterdam \\ Harry Wels \\ VU University Amsterdam
}

In an effort to embed diversity management in South African higher education, all Higher Education institutions are presently going through a transitional phase of transformation in which institutional cultures and identities are strongly contested. The ambiguity that comes along with such a process is illustrated through two rival "narratives of change" at North West University, presented in a number of reports and institutional publications that deal with the present state of transformation of the merged institution in this period of great institutional turmoil. In South Africa, the idea of diversity, widely spread and increasingly popular in the age of globalization, is linked to both societal redress and transformation, in a negative as well as a positive way. In the aftermath of apartheid the concept is sufficiently ambiguous to be used in these two rivaling narratives of transformation that are striving for hegemony.

\section{INTRODUCTION}

Universities are intersections of communication and debate that produce and reproduce knowledge (cf. Godin and Gingras, 2000). Academic research may be the fruit of individual thinking, but it can only flourish within a climate of critical debate, a "community of practice" (cf. Wenger 1998). A university can stand out if it is capable of supporting academic communities to thrive and cross-fertilize (cf. Westin, et.al., 1994). In the age of globalization and digitization, knowledge and ideas travel faster (cf. Introduction to this issue) in and between research communities than ever before, which has paradoxical consequences (cf. "glocalisation", Friedman, 1994). Academic communities themselves, on the one hand, have become more diverse in their composition. Diversity (cf. Janssens and Steyeart, 2001; Ghorashi, 2007) reigns in many fields, such as gender, ethnicity, religion, ideology etc., and is often considered an asset for achieving (academic) creativity and excellence (Adler, 2008). Diversity approaches, having their origins in the civil rights movement in the United States (Taylor Cox Jr., 2001), in South Africa got the particular (local) translation of striving for "transformation" and "redress", concepts that are often used interchangeably. A consequence of this is that globalization not only 
meant an accelerated spread of prevailing modes of scientific research. It simultaneously encouraged competition and power play between the various perspectives on academic excellence and creativity, the very things that the trend towards transformation tried to avoid and eradicate. Viewed from the center-periphery paradigm one might even maintain that Western trends in higher education (HE) have become ever more dominant, counteracting alternative, diverging knowledge concepts and undermining diversity and equality.

South African HE history provides illuminating material to demonstrate the complexity of academic development in a strongly diverse, but equally strongly segregated society. The concept has long had a rather "peculiar" meaning and the present understanding of diversity, which we could summarize, in line with the authors mentioned above, as an encounter of equals, has come a long way in South Africa's higher education. It was only since the 1990s, when democracy-for-all dawned for the very first time in South Africa, and particularly the late 1990s when the HE sector was turned upside-down by a large merger operation, that diversity received meaning outside the segregation and apartheid discourse and became a democratic policy goal, forcing former antagonist universities into a merged organizational structure. This pushed and challenged the dynamics of equality and power play, inherent to diversity, to the limits.

North West University (NWU) provides a highly relevant case to illustrate the paradoxical processes described above. As a merged institute it houses one of the most prominent former Apartheid campuses (Potchefstroom), next to an all-black "Bantu campus" (Mafikeng). It is considered one of South Africa's best-managed universities, proud of being an example of unity and equality in diversity; a place where diversity is highly valued, and given strong policy attention. It is firmly believed at NWU's top management that the university can contribute to diminish, and eventually abolish, ethnic inequality, as diversity is mainly understood. At the same time there was political unrest and upheaval in 2008 about the way "the old Potch" supposedly tried (once again) to force its norms of "proper science" upon its merger partner, which escalated to such an extent that the Minister of Education decided to install a national commission of inquiry to look into the matter.

By tracing back some of NWU's historical developments from an "only-for-whites" university to a mixed institution with ambitious and straightforward diversity goals, and including in this analysis its links with international partner universities (of which VU University Amsterdam was, and in some ways still is, a very prominent one, contributing to NWU's policies and choices through extensive interaction and consultancies in the post-1994 era), we hope to demonstrate how local university dynamics of power are affected by the idea of diversity that has traveled globally. We also point to the ambiguities that become manifest in university employees" behavior when a concept with such a wide variety of meanings are molded into lean management tools. Our interpretation and analysis of the case study is informed by a narrative approach to mergers.

\section{NARRATIVES ON MERGING AND DIVERSITY IN ORGANIZATIONS}

In the wake of the worldwide stream of mergers and acquisitions of the last decades organization studies have been prolific in their contributions on the theme (for an overview of the literature see Vaara, 2002; Angwin \& Vaara, 2005). Merging as an organizational change phenomenon has been studied from many angles: strategically oriented studies, human resourceoriented perspectives, and cultural perspectives. An important sub-theme in the merger literature is (the level of) post-merger integration, which is often described in terms of "success" and 
"failure". However, most of these studies - despite their cultural focus - pay little attention to the narratives produced by the main actors, or to the specific contexts in which actor perspectives are framed. Even within cultural perspectives, the strong focus on the variance in norms, values, and beliefs of merging organizations often ignores the complex interplay between culture and the political maneuvering of protagonists involved in merging processes. As Angwin \& Vaara (2005) argue in a special issue of Organization Studies, we need more documented and embedded research that goes beyond the myopia of many of the prevailing cultural perspectives, in which culture is often predicated as either favorable or averse to merging success.

Organizations can be viewed as socially constructed spaces where sense-making actors constantly try to change organizational reality (Bate, 1997; Van Maanen, 2010). Understanding the process of sense-making in a merged institution can be furthered by reconstructing the competing "narratives of change" out of the "tales from the field", as Van Maanen (1988) calls them. The complexity of merger processes, particularly in academic institutions, is often well expressed in the language used by their protagonists (Vaara, 2002; 2003). Scapegoating strategies and conspiracy theories are widely used as sense-making devices in this respect. They show the "discursive elements through which...phenomena are socially constructed and through which managerial actions are legitimized and naturalized" $(2002$, p. 237) by the main actors in their effort to continually frame and reframe the issue of failure and success.

Brown and Humphreys (2003) provide a good framework to analyze such merger debates. They distinguish between "epic" stories of interventionist successes in merging organizations, producing culturally coherent and effective new institutions, and their "tragic" counter-narratives. Managerial stories are often contradicted by such "tragic" tales, reporting on fragmentation and conflict, and in that way giving a diametrically opposite taxation of the success rhetoric. Brown and Humphreys (2002) base themselves on the storytelling approach advanced by Gabriel (2000, p. 35), who argues that rhetorical tropes are part of the poetic, interpretative story-work toolkit that organizational members have at their disposal. As Brown and Humphreys note, stories "are the means by which executives manage and the disaffected resist" (2002, p. 125). In South Africa, a similar analysis of higher education "merger tales" has been presented by Jansen (2003), whose approach we will adopt to analyze the rhetorical power struggle following the visit of a government committee to NWU to study reported irregularities supposedly representing the lack of transformation at the institution.

In response to the report of this task team, NWU management presented the success of its merger in terms of diversity, contrary to the team's critical counter-narrative that assessed the merger as merely a continuation of the divide that characterized the South African HE situation before it was "transformed" by government initiative in 2004. We will juxtapose these "epic" and "tragic" narratives on "transformation" to illustrate the contested character of diversity practice and rhetoric in South African Higher Education. Before we turn our attention to the case study of NWU, we will first contextualize the major shifts and developments in HE in South Africa, with a particular eye on the role and position of the Potchefstroomse Universiteit vir Christelike Hoër Onderwys, which became the leading partner in the NWU merger.

\section{THE SOUTH AFRICAN LANDSCAPE OF HIGHER EDUCATION BEFORE 1994}

The South African Higher Education Act of 1874 recognized certain already existing university colleges and also formally legitimized that the government would pay the salaries of the professors. Nevertheless it was only in 1916, six years after the 1910 Union of South Africa, 
that the government officially included universities in South Africa into a legal framework, with the Acts 12, 13 and 14 of that year (Sehoole, 2006, p. 7). The acts recognized three universities; the University of Cape Town, Stellenbosch University and the University of South Africa (UNISA), the latter also comprising the six already existing University Colleges and the Universiteit van die Kaap de Goede Hoop. The Potchefstroomse Universiteitskollege was formally put under the umbrella of UNISA in 1921 (Eeden, 2006, p. 28). In the years that followed the various universities under the umbrella of UNISA all became independent, starting with the University of the Witwatersrand in 1922 and the University of Pretoria in 1930. The Potchefstroomse Universiteit vir Christelike Hoër Onderwys followed in 1951 (ibid., p. 29).

In 1948 the Nasionale Party rose to power in South Africa and from that date onward racial segregation became institutionalized in more and more fields and spheres of life, including university campuses. An ever-increasing gap formed between the various racial groups in South Africa in terms of opportunities for education, with whites becoming increasingly privileged. Starting with the Bantu Education Act in 1953, higher education in South Africa became officially racially segregated, and the 1959 Extension of University Education Act (no. 45) was proclaimed prohibiting non-white students from registering at established universities any longer. Instead, specific universities were created for black, colored and Indian students. Prime Minister Verwoerd explained the Bantu Education Act was explained as follows: "They [racial relations] cannot improve if the result of Native education is the creation of frustrated people who, as a result of the education they received, have expectations in life which circumstances in South Africa do not follow to be fulfilled immediately" (Verwoerd in Sparks, 1991, p. 196). In other words, non-whites had to be taught to serve the needs of the white minority in South Africa. As a consequence, "[b]lacks inevitably saw this as education for inferiority" (ibid.).

The same rationale of racial segregation was followed throughout the education system, from primary to higher education. In 1983 for instance, as a result of racially segregated education, the apartheid government spent seven times more money on a white pupil than on an African pupil (Feinstein, 2005, p. 243). It "made education one of the most explosive grievances in the black community, and it provided the spark for both the 1976 student uprising in Soweto and, to a somewhat lesser degree, the great national convulsion that shook South Africa in the 1980s" (Sparks, 1991, p. 196). When Mandela came to power in 1994, Higher education in South Africa was to a large extent a racially segregated affair, and in South African public imagery (as in the rest of the world), Potchefstroom University for CHE was one of the icons of the scientific legitimating of apartheid, as many of its professors and other staff had been deeply involved with the secretive but very powerful Afrikaner Broederbond (Eeden, 2006, p. 493), as were many colleagues from other Afrikaans universities in South Africa (cf. Jansen, 2009, p. 206; Smith, 2009), throughout the apartheid years, and with the radical nationalistic Ossewa Brandwag in the 1930 and 1940s (cf. resp. Wilkins \& Strydom, 1978, on Broederbond, and Marx, 1998, on Ossewa Brandwag).

At the same time the apartheid discourse at Potchefstroom University was not of a monolithic or purely hegemonic kind. One example that we will use here because of the well-known name involved, is that of Willem de Klerk, brother of F.W. de Klerk, who as state president of South Africa released Nelson Mandela and unbanned the ANC in his famous speech to parliament on 2 February 1990. His brother Willem, nicknamed "Wimpie", was "plucked out of a professorship at Potchefstroom University to take over the editorship of the National Party's official mouthpiece, Die Transvaler" (Sparks, 1994, p. 79). It was known that Wimpie was "well to the left" (ibid.) of his brother, and that he partook in early secretive meetings with the ANC in the 
second half of the 1980s, about which he reported to his brother (cf. Sparks, 1994, pp. 79-80). The core of his message, based on his experiences with the ANC, was that contrary to popular belief amongst Afrikaners, it was possible to negotiate with them and that they did see "the Afrikaners as an indigenous part of the South African population" (ibid., p. 80). Wimpie as well as Sparks believes that these reports "had an effect" (ibid.) and contributed to the later "calling" of F.W. de Klerk to end apartheid in South Africa (cf. ibid., pp. 91-108). In order to understand the presence of this multi-vocality, perhaps even diversity, at Potchefstroom University during the apartheid years, we need to take a closer look at its origins and developments.

\section{POTCHEFSTROOM UNIVERSITY FOR CHRISTIAN HIGHER EDUCATION (PUK) ${ }^{1}$ UNTIL 2004}

On 20 May 1869, the Reformed Church started a theological seminary in Burgersdorp. The seminary was primarily set up to prepare and train more ministers for the church, as there was an acute shortage of those. At the same time the Synod promoted a broader vision, to not only train ministers, but also teachers. ${ }^{2}$ The seminary was officially opened on 29 November 1869 (Van der Schyff, 2003, p. 9). Generally, these dates are taken as the humble beginnings of Potchefstroom University for Christian Higher Education. The seminary moved from Burgersdorp to Potchefstroom in 1905 (ibid., p. 79). Because of its origins, right from the start the church had a very strong influence on the seminary and later the university. At first this influence could be deduced from the fact that all lecturers were also ministers at the church, and that two of the more important ones, Jan Lion Cachet and Dirk Postma (ibid.), were from the Netherlands. Potchefstroom's origins and early Dutch influences explain its close links with VU University Amsterdam, as this university was founded on reformed principles by Abraham Kuyper in 1880 (cf. Van Deursen, 2005, p. 19-22). It is well-known that Kuyper was a stern supporter of his "reformed brothers" in South Africa, to such an extent that at some stage in 1875 he even thought about emigrating to South Africa, as he believed Calvinism had greater possibilities in South Africa than in the Netherlands. ${ }^{3}$ Dutch-Afrikaner (Boer) relations remained close over a long period of time. When the Dutch ambassador to South Africa at the time, H.E. Jan van der Berg, spoke at the occasion of the new library in Potchefstroom in 1951 he said, amongst other things, that the Dutch and the Afrikaners served the same historical and spiritual ideals. ${ }^{4}$ Schutte, however, believes that "( $\mathrm{t}$ )he brotherly ties between the two institutions seem to have been felt more strongly in Potchefstroom than in Amsterdam" (2010, p. 65).

The opening up of the theological seminary in Potchefstroom to other disciplines apart from theology was partly the result of the fact that the South African government was not prepared to finance solely church-related education. A PUK internal commission at the time concluded that as long as the institution maintained its church-like character it could not apply for state support. ${ }^{5}$ From 1913 onwards, the seminary opened up, albeit rather hesitantly, to other disciplines in order to be granted the much-needed state subsidies. This progressive development towards other disciplines also had its repercussions in other fields, and in 1916 Helena Petronella (Lenie) van der Walt became the first female student to enter the Theological Seminary in Potchefstroom, (ibid., p. 171). In 1919 the theological seminary became the "Potchefstroome Universiteits Kollege vir Kristelike Hoër Onderwys" (ibid., p. 190) and in 1951 it was officially granted the independent university status.

In its continuous search for an identity, starting out in the globally turbulent 1930s and 1940s, and later as a university under the apartheid government, the PUK became a key player in the 
historical processes in South Africa. As a nation state, South Africa became increasingly isolated in the world due to its political ideology, and after the Sharpville riots in 1960, even the Netherlands distanced itself from South Africa (Schutte, 2010, pp. 123-169). "The turnabout in the Dutch position on South Africa was met with surprise, disappointment and annoyance by the Afrikaners" (ibid., p. 126). As a result of the general public opinion, PUK also came under increased attack for its pro-apartheid stance and position, and especially when VU University Amsterdam awarded an honorary doctorate to the staunch anti-apartheid theologian Dr. Beyers Naudé in 1972, it became clear that its relation with PUK could not continue. "It [VU University Amsterdam] cannot on the one hand award Dr. Beyers Naudé an honorary doctorate and on the other hand continue its close contact with fervent supporters of apartheid" (Andriessen, secretary of Kairos, in ibid., p. 141). On 17 August 1976 VU University Amsterdam cut all official ties with PUK (ibid., p. 161).

Although PUK is still generally considered to have been among the strongest upholders of apartheid ("apartheidbakermat", Eeden, 2006, p. 492), this public image does not completely do justice to the counter-voices that were also heard among staff and students at PUK (ibid., pp. 491-494). As always, this generalization leaves little room for relevant nuances, as the example of Wimpie de Klerk above already made clear. Another example that is telling in this respect is that of Theuns Eloff, rector of PUK from 2002, and from 2004 onwards of the merged institution that had become North West University. Eloff was chairman of the student council between 1977 and 1979 and in that capacity he urged all South African universities to open their doors to all South Africans, regardless of their color (ibid., p. 492). Furthermore, Eloff played a significant role in the democratization process in South Africa through participating in, and becoming the CEO of, the Consultative Business Movement (CBM), which, together with other parties paved the way for the 1991 National Peace Accord (Gastrow, 1995, p. 17). He was also part of the delegation that had secretive meetings with the ANC in Dakar as early as 1987 (Hopkins, 2006, pp. 73-74). Clearly, both the apartheid philosophy of diversity and more enlightened versions of diversity policies were present in Potchefstroom before the political overturn from 1994 onwards. However, the overall atmosphere has long and predominantly been pro-apartheid, and politically and religiously rather conservative. The recognition of South Africa as a multi-ethnic and diverse society was rarely made in this first and foremost Afrikaner institution. This started to change, albeit slowly, after the advent of democracy, when diversity became a prominent policy concept, particularly from the inception of the new NWU merger institution onwards.

\section{THE ROUTE TOWARD TRANSFORMATION: FROM PUCHE TO NWU}

When Nelson Mandela became South Africa's first democratically elected black president in 1994, apartheid officially came to an end and made way for a range of far-reaching policies and approaches that tried to redress the injustices and inequalities of the past. Informing most of these approaches was the notion that South Africa, apart from all kinds of new legislation, needed active quota to reverse situations of inequality because a majority of non-white people needed help to enter mainstream economical processes (instead of ethnic minorities, as is often the case in other countries like the US or in Europe) (cf. Spierenburg and Wels, 2004). Therefore South Africa adopted Affirmative Action as one of its "basic guides". 6 During this ongoing process, the Employment Equity Act was presented in 1998. "Besides the issue of equity, the Act explicitly refers to implementing policies of affirmative action" (ibid., p. 8, italics added). Transforming the institutions of higher education in line with this equity legislation and 
requirements was considered an important part of South African transformation as a whole (cf. Tamminga, 2004). At the beginning of the new millennium, the then Minister of Education, Kader Asmal, announced the names of several South African universities that were to merge, officially in order "to solve problems of duplication, fragmentation and lack of access in parts of the country and to improve the quality of education on offer". ${ }^{7}$ The total number of higher education institutions was reduced from 36 to 23, through a process of merging and closure. Amongst the institutions that had to merge were the predominantly white PUK and the much poorer and predominantly black University of the North West in Mafikeng (UNW). Geographically, Potchefstroom and Mafikeng are some 250 kilometers apart. The two institutions officially merged in 2004, just like other South African institutions such as Rand Afrikaans University in Johannesburg, and the University of Natal in KwaZulu-Natal (see Kamsteeg, 2008; also Boersma, et.al., 2008). The name of the newly merged institution in the North Western Province became North West University.

This merger between PUK and UNW was a most remarkable one. As we have seen, PUK had long been among the academic strongholds of apartheid, serving the white clientele of Transvaal, one of the most conservative areas in the country. UNW had grown out of the University of Bophuthatswana (UNIBO), one of the so-called Bantu colleges installed by the apartheid government to establish separate academic development in the homelands. UNIBO was relatively well-funded and attracted critical academics from other parts of the country and even from outside the country. With the democratic turn, the university was renamed University of the North West. It lost the financial support of the homeland government and was left in a marginalized position by the new central government, which led to an exodus of academics and a further divestment of the institution, until it was finally included in the NWU merger project, which clearly meant a challenging project in terms of diversity and transformation.

Four years down the line, in September 2008, the influential newspaper Mail \& Guardian $(M \& G)$ already reported on what is generally called the "merger mess". An official commission was appointed that had to come up with solutions to the observed problems. Professor Barney Pityana, Vice-Chancellor of UNISA at the time and one of the keynote speakers at the University of Johannesburg's Platform for Public Deliberation, was quoted by the M\&G on NWU, when he maintained that "the new institution is unmanageable. Effectively there are still two separate universities". If this contention shows anything it is that NWU had become one of the universities where the government policy of redress and affirmative action faced a major challenge. However, the university itself, and particularly its management, had adopted "Innovation through diversity" as its main policy goal. In 2008 NWU's Institutional Plan suggested that "after its first three years, [it has] achieved most of the objectives set out in the Merger and Incorporation guidelines of the Department of Education" (NWU, 2008, p. 1). These guidelines focus on the principles of university governance in terms of teaching-learning output, research output, financial viability, etc., covering all three NWU campuses (Vaal Triangle, previously a satellite campus, was separated from Potchefstroom to become an independent campus). This is not to say that university management, through its Institutional Office, did not recognize that the merged parties still had a long way to go before becoming a well-integrated and diverse institution. Its vice-chancellor, Theuns Eloff, however, claims that sufficient progress has been made to justify the contention that NWU "can in many ways be considered an exemplary merger, not in the last place because of its financial successes" (NWU, 2009, p. 3). We will discuss rivaling opinions in the next section. 
Disputes of merger successes and failures show that Higher Education politics in South Africa constitute a politically sensitive issue and their assessment largely depends on the position of the protagonist. What may seem a major step forward to some, to others is just a tiny gesture with little more than symbolic value. Expecting the NWU merger to complete the envisioned redress measures and the establishment of a really diverse and diversified institution within five years was probably unrealistic, given the ingrained inequalities between the historically all-white campus in Potchefstroom, and its Mafikeng "counterpart". Yet the debates about merger successes and failures, focusing on the diversity issue, are certainly instructive about the organizational change that is still taking place in South Africa's universities. The above-cited verdict by Pityana on the approaches to diversity of NWU may be one-sided, and even openly ignores the specific policies that NWU has developed in order to foster a more diverse staff and student population, yet it shows the urgency of the problem, and the political priority it has in today's complex Higher Education situation in South Africa.

This dilemma between the need for speedy transformation and the pertinacity of old structures and, perhaps even more importantly, cultures, as well as the varied assessment of the process, is the subject of the next section. In this section, we will attempt to give a balanced perspective on this highly sensitive topic, by analyzing the diverse positions and contestations of the concept of diversity in higher education, as they become visible in the sometime heated discussions. We will do so by giving a detailed analysis of the rhetoric deployed by some key players in the NWU merger process, which more than anything else illustrates the extent to which the diversity concept is subject to (political) sense-making.

\section{RIVALING NARRATIVES ON DIVERSITY}

The analytical tragic-epic narrative framework presented above can be used to interpret some incidents taking place during the NWU merger process in 2008, which appear as a narrative and counter-narrative of merger success. In that year several critical incidents occurred at the NWU Mafikeng campus, which led to a government-installed fact-finding committee visiting the university in October of that same year. The campus, located on the Botswana border in the rural Tswana hinterland of the Gauteng mining zone, was closed two times during the 2008 academic year. Students blocked the main entrance, burned tires and prohibited class attendance, upon which university management suspended classes and exams for several weeks. In the recent past of South Africa's higher education history, campus unrest has not been unusual, but this was the first serious case of campus closure after the restructuring of the sector. The Minister of Education decided to install a task team (TT, from now on) to investigate the causes of the incidents, and more broadly how the NWU merger had been doing in terms of the wider transformation the ANC government was aiming for. This investigation into the behavior of one of South Africa's important higher education players became a test case of the government's restructuring policy. ${ }^{9}$ What follows is an analysis of the final report on "failed transformation" 10 by the TT to the then Minister of Education Pandor. We typify this narrative as tragic, in contrast to the epic "counternarrative" presented in two reactions to the TT report, written by NWU's vice-chancellor since 2004, Theuns Eloff, which will be presented subsequently.

\section{The Tragic Narrative}

The TT report published in 2009 in the official Government Gazette tells a story that stresses the flaws of the multi-campus merger of NWU. This story is based on a site visit that consisted 
of 'six days listening to over 387 individuals representing various constituencies in the University" (Government Gazette, 2009, p. 59). The TT, evaluating the viability of the NWU as an institution, characterizes the university as performing "well above national averages...as an aggregate organizational entity...[that is] doing well and seems set to play an important role in the North West Province, and has even more potential to play a greater role nationally" (ibid., p. 61). This assessment, based upon student success rates, staff performance, financial situation, multilingualism and governance, strongly contrasts the TT's grim testimonies of failure in the field of "overcoming the apartheid-induced divide between historically white and historically black institutions", which, next to "promoting a more equitable staff and student body", was one of the two strategic goals of the merger as published in the same Government Gazette. However, this judgment, stressing the improved university's efficiency and results, seemed only the benevolent overture preceding an assessment on the transformation and redress part of the merger process that was far more negative in tone. This part of the TT report predominantly refers to "causes for disruptions...integrating policies and practices across all campuses...enhancing social cohesion and a new institutional culture" (Government Gazette 2009: 14-15). What follows after the positively framed introduction is the portrait of a neglected black campus at Mafikeng, subjugated by the still predominantly white and dominant Potchefstroom campus where the main administrative hub, called the institutional office, also resides. The third campus, Vaal triangle, is portrayed as a place well positioned to become the exemplary redressed university of the new era, with a "progressive campus culture that tries to inculcate a sense of oneness and an appreciation of the diversity of its student population" (ibid., p. 54). The story is based on testimonies by staff, management, council, forum, and students from each campus, (sometimes) supported by anonymous letters of information. As to the Mafikeng campus, the TT finds proof of "a generally poor staff work ethic" and a situation that "staff, and also students...commonly and indignantly refer to as the "Potchification" of the NWU" (ibid., p. 14). The local management, faced with the disruptions and campus protests, is characterized as expressing "a sense of desperation with..."external" influences on the University... [not having a] plan or mechanism to deal with them". This description portrays a campus playing the role of a "puppet on a string" to the Potchefstroom campus/Institutional management. The cited student and staff declarations also point to the "fractured relationship between management and themselves", leading to a demand for "the resignation of both the Campus Rector and the Vice-Chancellor". (ibid., p. 17). The merger is characterized as "a marriage of convenience", in which the one partner Potchefstroom is 'suffocating Mafikeng", a phenomenon reflected by the hostilities around the new logo, [which is] 'seen as the symbolic expression of the federal structure...with Potchefstroom campus permanently on top, in a dominant position" (ibid.).

Testimonies collected by the TT at Potchefstroom - considerably less pages are spent to this campus - reveal that its management acknowledges that equity and redress still constitute a significant challenge, despite the fact that integration is taking place during social events and sports meetings. Specific meetings with students, including members of the Student Representative Council (SRC), are presented by the TT to show strong discrepancies between black and white students in terms of (cultural) in- and exclusion. The TT concludes that "white students saw their black counterparts almost as guests ("non-whites"), and not as equals" (ibid., p. 26; see also NWU, 2007).

In its conclusion about the Mafikeng disruption the TT maintains that the current situation of distrust by staff and students at this campus has been a major incentive (with distrust of 
management, supposed bad administration, and a failing Rector) for external (political) forces to try and disrupt university policy and practices. A persistent lack of cooperation with the other campuses, notably Potchefstroom, is deduced from the practice of curriculum change, or alignment. Mafikeng academics view this assumed joint effort as a predominantly one-way traffic process. Here the TT does little to conceal its mistrust of the Institutional Management's (the overarching governing body of the university) claim of real progress. The TT establishes a "deep sense of inequality", stating that

"...the overriding impression given was one of an astounding lack of collaboration. None of the staff present had co-taught a course at Potchefstroom or Vaal campuses, nor had anybody from Potchefstroom come to their department. The TT was not told about any plans or funds for staff or student exchanges between the campuses." (Government Gazette, 2009, p. 30)

The report ends by expressing the view that the "near terminal loss of trust, common vision and even sense of decorum between management, students, organised labour and general academic and support staff at Mafikeng campus" are unlikely to be resolved by the "legalistic" and 'security" oriented approach of management (ibid., p. 33).

This rather tragic picture is further corroborated by the TT's evaluation of the multi-campus governance model that is blamed for the failed integration, as "it is not the strong problemsolving management model that is needed if unequal institutions with vastly different cultures and practices are to "merge"" (ibid., p. 38). The slow and irregular program alignment, and uneven and weak results on most other academic performance indicators - none of the scientific publications being the result of a collaboration between scientists from different campuses - next to a language policy that black staff and students regard as favoring Afrikaans speakers and a "labour relations policy that failed to develop an inclusive and functional labour relations system" are presented as so many signs of failing institutional integration. This implies that the TT believes that the merger has thus far been unable to produce signs of a single institutional culture, a conclusion earlier reached by the Council of Higher Education with respect to the merged HE sector as a whole (Higgins, 2007). Hence the reader of the TT report is left with a picture of a hopelessly divided university, inhabited by both demoralized and detached students and staff, ruled by a management that is either incapable or unwilling to see this reality, and lacks the policy framework to infuse diversity into the institution as an instrument of effective transformation and equity, and with no "sufficient social life and interaction among the three campuses, except for the three official days a year designated for social networking" (ibid., p. 58).

At the end of the TT report we read that the team has come to these conclusions in an atmosphere that can hardly be called favorable for unbiased fact-finding. It is contended that 'senior management displayed doubt, lack of trust and paranoia about the intentions of the Minister in appointing the TT, regardless of the documented terms of reference", and that the team had to confront questions about its legitimacy and good faith, and a community biased by a tendentious newsletter by the Vice-Chancellor. Thus the members of the team left an institution that showed "a sense of deep mistrust...about the Minister's motives in appointing them" (ibid., p. 59).

The recommendations by the TT were certainly food for further distrust. In its report, the Mafikeng campus management is strongly discredited for being incoherent and indecisive. The 
TT even hints at "redeployment" (ibid., p. 62). The Department of Education is advised to take the lead in establishing a joint forum with the community in which the campus operates, in order to find a political solution for the permanent state of contestation infringing the campus. Taken together these suggestions disqualify NWU's Mafikeng campus leadership as a capable player in the field. Consequently NWU's general management is suggested to reconsider its academic project "to become a single university". This seems to imply that the other campuses are to help the Mafikeng campus to strengthen "a selected number of strategic areas", in which students would receive preparatory education, before being further educated on one of the other two campuses. This suggested degradation of the Mafikeng campus is probably the strongest verdict on the success claim of the NWU merger, but there is more. NWU is advised to terminate the apparently non-productive social functions and to spend the money on substantial exchange programs instead. This would mean a real effort to make Potchefstroom campus more diverse, and to finally establish a more inclusive institutional culture, especially at Potchefstroom campus. Taken together the report delivers a powerful message of an unfinished, if not failing, merging project, in which diversity does not lead to innovation but rather functions as a symbol of the perpetuation of past divisions. This demonstration of governmental power play could of course not remain unchallenged by NWU, whose leader took the responsibility to develop a counternarrative.

\section{The Epic Narrative}

One year after the report of the TT to the Minister, NWU Vice-chancellor Eloff reflected on the events of the year 2009 in a Newsletter to the university community. He started with the expected positive outcomes of the Higher Education Quality Committee's institutional audit, and recalled the fact that NWU won the Price Waterhouse Coopers award for best corporategoverned university in South Africa. He characterized the year 2009 as one with uninterrupted academic activities and stability on all campuses. The latter clearly referred to developments on the Mafikeng campus as a result of better communication and improved relations between all stakeholders, including students. What is more, all stakeholders were said to have engaged in issues of transformation and social cohesion. Special attention was given to the progress made in the field of academic program alignment and a small but significant header boldly announces that "we have (finally) merged!" This assertion was supported by referring to the outcome of meetings and publications in the popular press in which NWU was lauded for being "far ahead of the sector in terms of core business, systems and processes" and "the only institution that provided statistics on successes of the merger, including undergraduates pass rates, research outputs, innovation activities and financial stability". The Minister's Merger Unit (not the TT) was also mentioned as being "extremely satisfied with the successes...achieved" (NWU, 2009c, n.p.). These proud statements perfectly resemble the extensive narrative Eloff produced almost a year earlier, in reaction to the "tragic" TT report on transformation. At that time, he apparently felt obliged to respond to the "allegations" presented in the TT report and explain his view on the merger so far. In a reaction sent to the Mail and Guardian, one of South Africa's most authoritative newspapers, he started by enumerating NWU's recent prizes, won for multilingualism, good governance, and innovation. Next he questioned the legitimacy of, and defective methodology used by the TT ("outside of the HE Act provisions"), which he qualified as superficial, untested, erroneous, based on hearsay. Although he claimed he would use the TT conclusions as a source for further introspection, he provided a list of examples demonstrating that the research on which these were based could hardly be taken seriously. Particularly the 
allegations with respect to the progress at Potchefstroom on the issue of diversity were strongly contradicted. These allegations were either "prescribed" (with regard to "archaic initiation practices"), "based on anonymous reports" and "devoid of truth", or denying recent policy and practice changes (with regard to allegations of "racism" and "preservation of Potch as a white and Afrikaans campus"). He recognized that staff transformation (indicating the level of change in its ethnic composition) had been slow, but stated that the TT had not taken notice of the set targets and the way the process was being monitored. According to Eloff, the distrust and miscommunication on the part of one campus (a clear reference to Mafikeng), as presented by the TT, was based on only "a small minority of staff and students (that) thrive on rumours and unfounded allegations. To blame this on management (as if the mistrust is their fault) is at least ingenious and at most malicious" (above references all from NWU, 2009a, p. 3).

In a more extensive special newsletter - backed by the university council - Eloff directed himself to the NWU community as a whole (NWU, 2009b), explaining the negative publicity NWU had received as a result of the TT report (which was made available through the NWU website). This newsletter was a well-crafted statement, telling a fully fletched organizational story on the basis of a distinction between (and actually playing with the concepts of fact and fiction (cf. Gabriel, 2000). In this rhetorically powerful letter, Eloff labels ten "facts" he considered important. Five of them were negatively formulated and focus on the workings of the TT:

1. The appointment of the Ministerial Task Team was not in line with the provisions of the HE Act; [implication: the report is illegal, FK/HW]

2. The TT hardly spent enough time at the NWU to do an in-depth investigation and analysis; [implication: sloppy work has been done, FK/HW]

3. The report failed to distinguish between fact and reality on the one hand, and untested allegations, perceptions, total untruths and even malicious rumors on the other; [implication: the report is not to be taken seriously from a scientific point of view, FK/HW]

4. NWU was not allowed the opportunity to comment on the factual issues in the Report; [implication: the text contains errors, FK/HW]

5. The so-called "audi alteram partem" rule was not adhered to. [implication: the report is consciously partial, FK/HW]

The other five focused on the efforts made by NWU itself:

1. NWU is totally committed to make our merger a success and to achieve the merger objectives;

2. Mergers are long-term projects and indeed NWU has not yet overcome all its challenges (here a scientific article is quoted to prove the veracity of the statement); [implication: significant successes have been achieved, FK/HW]

3. NWU is willing to treat the relevant aspects of the Report as a tool for ongoing introspection; [implication: NWU is willing to accept criticism when deemed relevant, FK/HW]

4. There is no alternative for the present governance and management model of the university, which the TT claims is failing (despite recognizing that it has worked well on 
one of NWU's campuses); [implication: the TT report does not understand the reality of merging, FK/HW]

5. NWU deliberately started with a focus on quality and efficiency, while simultaneously following a parallel route of equity transformation - and this has worked well. This statement is followed by the earlier list of achievements and prizes, adding the most recent positive result in student pass rates. It finishes with the equity targets for staff profiles; [implication: NWU does have an overview of the complete process of organizational change and consider themselves right on track with regard to its equity targets, FK/HW]

Following on these "facts", six "fictions" were presented:

1. With regard to the allegations about widespread racism at Potchefstroom campus and to a lesser extent at Vaal Triangle campus: according to Eloff, this statement is based on isolated remarks by students at Potchefstroom campus, who are both undeniably wrong in their formulations, and in no way representative;

2. The presumed racism at NWU is said to be visible in NWU's language policy, which in the report is characterized as a policy of separate development [a very serious reference to the old days of apartheid, FK/HW]. Generally positive student evaluations, however, are denied, as well as the fact that most of the language policy is directed at promoting the understanding of English;

3. The Mafikeng campus is considered to be in a "terminal state of decline academically". Investments to improve the campus" academic performance are systematically neglected, or misinterpreted by the TT. Notwithstanding the progress that is being made, Eloff admits that Mafikeng does provide some "challenges" (e.g. with regard to research output) and that "further investment" is necessary;

4. The conclusion that the student unrests of 2008 had a reasonable basis and were the result of bad management is flatly denied by Eloff; instead he attributes the disruptions largely to political maneuvering and trade union interference. Management is falsely accused of being legalistic and uncompromising - which Eloff considers laudable because it implies management has been adhering to the law;

5. Restructuring and redeploying Mafikeng Campus Management is said to be the reasonable thing to do. How can the TT assert this on the basis of a one-hour meeting with that same management?, Eloff writes exasperatedly. Besides, the university council has investigated student and staff complaints and found them lacking in substance;

6. Students are not treated equally at the different campuses. This reference to rule offenders from Mafikeng and Potchefstroom being punished differently, is dismissed as untested and untrue. Eloff does, however, suggest a reconsideration of the consistency of NWU's disciplinary code.

Eloff finished his tale by expressing the hope that "the framework of "facts" and "fictions"" would give the NWU community an idea about the approach of management to what he called "this difficult issue", and announces faculty visits to discuss it further. He suggests that all this should be "gradually put behind us", because "it is in succeeding and performing well in our core business that we will eventually silence our critics, internally, as well as externally..." (NWU 2009b, n.p.). 
This rhetorically powerful statement can be seen as a significant step in the process of aligning institutional sense-making. The case also seems to suggest that a narrative approach to issues of sense-making can provide a worthwhile hermeneutic tool for interpreting the various discourses presented in this case. Interestingly, there is an almost ironic twist in this facts/fictions narrative. Theuns Eloff consciously decides to play the narrative and story card, ridiculing the "facts" presented in the TT report as (nonrepresentative) stories and fictions, while at the same time using and presenting his (success) stories as (representative) "facts".

Although the diversity concept does not play a preeminent role in either of the two narratives, the underlying issue in the debate about the extent to which the NWU merger is successful is precisely about the question whether or not the transformation has resulted in diversity, in terms of equal chances and representation of the ethnic groups that under apartheid were viewed and treated from a totally different diversity perspective.

\section{CONCLUSION}

"Diversity" has universal appeal for organizations (cf. Shortell and Kaluzny, 2006, p. 9). No appealing idea that "travels the world", however, can land and leave again without being scratched, impregnated and altered by the local contexts in which it is used in socio-economic and particularly in socio-political configurations. The concept of diversity has also set foot in South Africa and has become a popular word in all sectors of society, including higher education. Although especially in higher education contexts the concept is still often viewed with some ambiguity, it is gaining wider credibility as an asset in this field (e.g. Brink, 2009). Despite their global and universal odor, however, wherever ideas take root, they get a global (cf. Friedman, 1994) flavor. Diversity in South Africa's higher education cannot be grasped without a local contextualization, with its clear remnants of an imperialist and apartheid past.

In this contribution we have tried to deal with this changing context in South Africa, while simultaneously elaborating on a specific case of contested organizational change. This contestation concerned the implementation of a merger process at the North West University. Our contextualized narrative approach has hopefully provided some insight into the complexities of organizational change, particularly if the changes relate to broad issues such as social transformation and redress in a hugely diverse society. It has not at all been our intention to establish which NWU narrative on transformation and success of the merger is "more true" than the other. What we have presented in this article is on the one hand a clearly epic story promoted by (top) management, which forwards its champions of transformation, achievement, success, mission, quest and sacrifice (Gabriel, 2000, p. 84) towards making a success out of the political merger project. There is pride, and some postalgic projection (i.e. of an idealized past onto the future, cf. Ybema, 2004) involved in turning diversity into an asset, and a source of innovation. The multi-campus university is presented as being well on its way toward redressing the diversity cleavages of the past into the desired state transformation where diversity goes hand in hand with equal opportunities. On the other hand we have presented a counter-narrative of the tragic kind, transmitted through the government's TT report, which depicts a grim story in which the new transformation and diversity discourse is little more than a loincloth, hardly capable of covering up the fathoms of the apartheid past. The image of the black Mafikeng university community as the non-deserving victim of the white Potchefstroom villain, is still very powerful in its appeal on traumatic experiences, feelings of loss, anger, fear, and blame (ibid.). 
What these tales also make clear is that the concept of diversity, so closely linked to redress and transformation, is a highly sensitive one, that is subject to permanent institutional contestation. Echoes of the past still give the concept a somewhat bitter (after)taste, which can explain why the "innovation through diversity" slogan rouses such ambiguous reactions and responses. The critical incident we used to demonstrate the vicissitudes of the concept in the South African Higher Education context is indeed much more than a coincident. The analysis presented speaks of narratives that to a certain degree represent contesting "epic" and "tragic" versions of "transformation" that play a role in South African higher Education at large. And even beyond the educational field it points to the fierce discussions and struggles over civil transformation that are actually taking place in South Africa. The higher education sector and its restructuration and merging project is only one of the fields in which this battle is being fought, and the NWU case as represented by two "telling" tales makes clear that studying the politics of sense-making can deepen our understanding of this complex phenomenon.

We would like to end on a positive note. As the brief historical overview of both campuses also shows, next to postalgia (Ybema, 2004), is that there is a strong feeling of organizational nostalgia (Gabriel, 2000) about the old days of Potchefstroom and Mafikeng, not necessarily or even primarily in terms of a (political) longing for a kind of restoration of the past, but more in terms of a sense of pride about what has been accomplished in the recent past and present. This history shows that institutional life for both Mafikeng and Potchefstroom has always been an uphill struggle, in which the government has been and always will be a key player. Although nos/postalgia can be found in the narratives of both sides, they are of course of a different nature, as the political loyalties and configurations have been so divergent. Perhaps Eloff's epic tale could be interpreted as an attempt to prove the success of a merged, diverse university, but also as an effort to merge the senses of pride based on the earlier achievements of the two independent universities.

\section{ENDNOTES}

1. The correct English abbreviation for Potchefstroom University for Christian Higher Education would be PUCHE; however, it is commonly referred to as 'PUK'(Potchefstroom Universiteits Kollege in Afrikaans); for historical reasons we will refer to it as PUK in this article.

2. “dat er niet alleen predikanten aangevormd worden, maar ook jongelingen zich kunnen bekwamen tot onderwijzers der jeugd, ja dat ook jongelieden, zonder een bestemd doel te hebben, gelegenheid gegeven wordt, naar hunne vatbaarheid gebruik van de school te maken, allen onderworpen aan de regulatien der school" (Reformed Synod in Van der Schyff, 2003, p. 2).

3. "omdat hy op daardie tydstip " $n$ groter toekoms vir die Calvinisme in Suid-Afrika gesien het as in Nederland" (Van Deursen, 2005, p. 131).

4. 'sowel die Nederlanders as die Afrikaners kragtens hulle geskiedenis in diens staan van dieselfde geestelike ideaal" (ibid., p. 472).

5. "zo lang het zyn kerkelik karakter behoudt, is het, onder de bestaande regulaties niet gerechtigd op een staatstoelaag ..." (in Van der Schyff, 2003, p. 127).

6. See www.labour.gov.za/ under "basic guides', third bullet "Basic Guide to Affirmative Action (accessed 8 November 2010).

7. See www.southafrica.info/ess_info/sa_glance/education/higheredplan.htm (accessed 8 November 2010).

8. See www.mg.co.za/article/2008-09-16-untangling-the-merger-mess (accessed 8 November 2010).

9. In March 2008, the then Minister of Education, Mrs Naledi Pandor, also announced the establishment of a Ministerial Committee to "investigate discrimination in public higher education institutions, with particular focus on racism and to make appropriate recommendations to combat discrimination and to promote social cohesion". The Committee was chaired by University of Cape Town Professor Crain Soudien. The 
document was released for comment in November 2008, and critically reviewed in the bulletin of HESA (see Soudien, 2008; HESA, 2010).

10. Including a separate report for the TT written by CHET director Nico Cloete.

\section{REFERENCES}

Adler, N.J. with Gundersen, A. (2008) [2002]. International Dimensions of Organizational Behaviour. Mason: Thomson. Fifth Edition.

Boersma, F.K., Reinecke, C. and Gibbons, M. (2008). Organizing the University-Industry Relationship: A Case Study of Research Policy and Curriculum Restructuring at the North-West University in South Africa. Tertiary Education and Management, 14(3): 209-226.

Brink, Chr (2009). 'standards Will Drop" - and Other Fears about the Equality Agenda in Higher Education. Higher Education Management and Policy, 21(1): 1-16.

Brown, A.D. and Humphreys, M. (2003). Epic and Tragic Tales: Making Sense of Change. The Journal of Applied Behavioural Science, 39(2): 121-144.

Cox, T. Jr. (2001). Creating the Multi-cultural Organization. A Strategy for Capturing the Power of Diversity. San Francisco: Jossey-Bass.

Cross, M. (Ed) (1999). No Easy Road: Transforming Higher Education in South Africa. Cape Town: Maskew Miller Longman.

Dackert, I., Jackson, P.R., Brenner, S.-O. and Johansson, C.R. (2003). Eliciting and Analysing Employees" Expectations of a Merger. Human Relations, 56(6): 705-725.

Deursen, A.Th. van (2005). Een Hoeksteen in het Verzuild Bestel. De Vrije Universiteit 18802005. Amsterdam: Uitgeverij Bert Bakker.

Department of Education (2008). Report of the Ministerial Committee on Transformation and Social Cohesion and the Elimination of Discrimination in Public Higher Education Institutions. Pretoria: Department of Education [the so-called Soudien report].

Government Gazette (2009). Report of the Investigation by the Ministerial Task Team into the North-West University, 31863, February 4, 2009. Pretoria: Department of Education.

Eeden, E.S. van (2006). In U lig. Die PU vir CHO van selfstandigwording tot samesmelting, 1951-2004._Potchefstroom: Noordwes Universiteit, Potchefstroomkampus.

Feinstein, C.H. (2005). An Economic History of South Africa. Conquest, Discrimination and Development. Cambridge: Cambridge University Press.

Friedman, J. (1994). Cultural Identity and Global Process. Thousand Oaks, London: Sage Publications. 
Gastrow, P. (1995). Bargaining for Peace. South Africa and the National Peace Accord. Washington: United States Institute for Peace.

Gabriel, Y. (2000). Storytelling in Organizations. Facts, Fictions, and Fantasies. Oxford: Oxford UP.

Ghorashi, H. (2007). The Paradoxes of Cultural Diversity within Organizations. The International Journal of Diversity in Organisations, Communities \& Nations, 7(5): 223-229.

Gibbon, P, Habib, A., Jansen, J., Parekh, A. (2001). Accounting for Change: The Micro-politics of University Restructuring. South African Journal of Higher Education, 15(1): 15-46.

Godin, B., and Gingras, Y. (2000). The Place of Universities in the System of Knowledge Production. Research Policy, 29: 273-278.

Harman, K. (2002). Merging Divergent Campus Cultures into Coherent Educational Communities: Challenges for Higher Education Leaders. Higher Education, 44: 91-114.

HESA (2010). Sector Response to the "soudien" Report._Insight, 2: 5-7.

Higgins, J. (2007). Institutional Culture as Keyword. Review of Higher Education in South Africa. Pretoria: The Council on Higher Education, pp. 97-123.

Hopkins, P. (2006). Voëlvry. The Movement that Rocked South Africa. Cape Town: Zebra Press.

Jansen, J., Bindi, N., Chalafu, S., Lethoko, M., Sehoole, C., and Soobrayan, V. (Eds) (2002). Mergers in Higher Education, Lessons Learned in Transitional Contexts. Pretoria: University of South Africa Press.

Jansen, J. (2003). Mergers in South African Higher Education: Theorizing Change in

Transitional Contexts. Politikon: South African Journal of Political Studies, 30(1): 27-50.

Jansen, J.D. (2009). Knowledge in the Blood. Confronting Race and the Apartheid_Past. Stanford: Stanford University Press.

Janssens, M. and Steyaert, C. (2001). Meerstemmigheid: Organiseren met verschil. Leuven: Universitaire Pers; Assen: Koninklijke Van Gorcum.

Kamsteeg, F.H. (2008). In Search of a Merged Identity: The Case of Multi-Campus North-West University, South Africa. TD The Journal for Transdisciplinary Research in Southern Africa, 4(2): 431-451.

Marx, C. (1998). Oxwagon Sentinel. Radical Afrikaner Nationalism and the History of the Ossewabrandwag. Berlin: Lit Verlag. 
North West University (2007). NWU Culture and Climate Study 2007: Analysis of Results and Interpretative Report. North West University: What Works Strategic.

NWU (2009a). Comment to the Mail and Guardian by NWU on Report of the Ministerial Task Team into the Affairs of the University. Available from:

http://www.mg.co.za/uploads/2009/02/13/nwucomment.pdf, last visited 20 February 2012.

NWU (2009b). Newsletter, 27 March. Available from:

http://www.nwu.ac.za/webfm_send/10580, last visited 21 February 2012

NWU (2009c). Newsletter, 2 December. Available form: cms-lnx1.nwu.ac.za:8080/opencms/nwu/i-news/electronic_newsletters/VC_Newsletter/2009/VC_Newsletter20091202_a.html, last visited 23 November 2011

Risberg, A., Tienari, J., and Vaara, E. (2003). Making Sense of a Transnational Merger: Media Texts and the (Re)construction of Power Relations. Culture and Organization, 9(2): 121-137.

Schutte, G. (2010). A_Family Feud. Afrikaner Factionalism and Dutch Neo-calvinism. Amsterdam: Rozenberg Publishers.

Schyff, P.F. van der (2003). Wonderdaad...! Die PUK tot 1951: Wording, vestiging en selfstandigheid. Potchefstroom: Potchefstroomse Universiteit vir Christelike Hoër Onderwys.

Sehoole T. (2005). The Politics of Mergers in Higher Education in South Africa. Higher Education, 50: 159-179.

Sehoole, C. (2006). Internationalisation of Higher Education in South Africa: A Historical Overview. Perspectives in Education, 24(4), December: 1-13.

Smith, N. (2009). Die Afrikaner Broederbond. Belewinge van die binnekant. Pretoria: Lapa Uitgewers.

Sparks, A. (1991). The Mind of South Africa. The Story of the Rise and Fall of Apartheid. London: Mandarin.

Sparks, A. (1994). Tomorrow is Another Country. The Inside Story of South Africa's Negotiated Revolution. Sandton: Struik Book Ditributors.

Spierenburg, M. and Wels, H. (2004). The Search for Equity in Organization and Management in South Africa. In: M. Spierenburg and H. Wels, (Eds). Culture, Organization and Management in South Africa. In Search of Equity. New York: Nova Sciences. Pp. 1-18.

Tamminga, W. (2000). The Doors of Learning Shall Be Opened. In: M. Spierenburg and H. Wels, (Eds). Culture, Organization and Management in South Africa. In Search of Equity. New York: Nova Sciences, pp. 19-46. 
Tienari, J. (2000). Gender Segregation in the Making of a Merger. Scandinavian Journal of Management, 16: 111-144.

Vaara, E. (2002). On the Discursive Construction of Success and Failure in Narratives of Postmerger Integration. Organization Studies, 23(2): 211-248.

Wenger, E. (1998). Communities of Practice: Learning, Meaning, and Identity. Cambridge: Cambridge University Press.

Westin, S., Roy, M. and Kim, C.K. (1994). Cross-fertilization of Knowledge: The Case of MIS and its Reference Disciplines. Information Resources Management Journal, 7(2): 24-33.

Wilkins, I. and Strydom, H. (1978). The Super-Afrikaners. Inside the Afrikaner Broederbond. Johannesburg: Jonathan Ball Publishers.

Ybema, S. (2004). Managerial Postalgia: Projecting a Golden Future. Journal of Managerial Psychology, 19(8): 825-841. 